\title{
Urban sprawl management, smart growth: challenges from the implementation phase
}

\author{
Claudia Trillo \\ Interdepartmental Laboratory of Territorial Planning (LUPT), \\ University 'Federico II' of Naples, \\ Via Toledo 402, Naples, 80134, Italy \\ E-mail: claudia.trillo@unina.it_E-mail: C.Trillo1@Salford.ac.uk
}

\begin{abstract}
In the mid-90s in the USA, the smart growth movement emerged, promoting a blended approach to urban sprawl management. This paper aims to explore the potential of smart growth to contribute in the achievement of effective urban sprawl management. To do that, it investigates the incentive-based, regionally-led approach undertaken in the San Diego region. In this example, a regional comprehensive plan which embeds smart growth concepts is currently carried out by an association of governments (SANDAG). Although lacking in land-use powers, SANDAG rests on a wide range of incentives, which should encourage recalcitrant local authorities to put the regional plan forward. The paper concludes that an incentive-based approach can lead to very positive results. However, it can work even better in conjunction with a regulatory framework in order to fill some specific gaps which can occur during the implementation process of the plan.
\end{abstract}

Keywords: smart growth; growth management; incentive-based approach; San Diego region; sustainable urban form; urban sprawl management.

Reference to this paper should be made as follows: Trillo, C. (2013) 'Urban sprawl management, smart growth: challenges from the implementation phase', Int. J. Society Systems Science, Vol. 5, No. 3, pp.261-282.

Biographical notes: Claudia Trillo received her PhD in Urban Design and is an experienced Consultant in Urban Planning. She is the Director of the Centre for Development Policies at the LUPT, University of Naples and the Director of the Fondazione Astengo, INU, Rome. As a Lecturer at the University of Ulster, UK, and a Fulbright Senior Researcher at San Diego State University, USA, she developed a wide range of research interests at international level, including smart growth, TODs, sustainable urban design and regeneration, community planning, transfer of development rights, local and regional development. She is currently involved in three EU research projects on sustainable urban regeneration, city safety and security and competitiveness of lagging behind regions. She is also an International Fellow at the SOBE, University of Salford. She employs a trans-scalar approach in order to interpret and manage the planning issues in the framework of the multi-layered governance system.

\section{Introduction}

Currently, a general consensus exists on what sustainable urban form means. It has been proved that compact development patterns considerably reduce the environmental costs 
of transportation, which are responsible for a significant amount of $\mathrm{CO}_{2}$ production (Ewing et al., 2007). They are more sustainable in environmental terms (Farr, 2007), especially because a dense pattern of settlement, supported by an efficient transportation network, allows to save land and to reduce car dependency (Calthorpe, 1993; Calthorpe and Fulton, 2001; Cervero and Bernick, 1997).

Modellers still lack tools for precisely evaluating the influence of urban form on the amount of greenhouse gases (GHGs) production (Condon, 2008), and as a result of this knowledge gap, decision makers' attempts to demonstrate their results when addressing climate change are often challenged. However, the literature is almost in concord in claiming that dispersed patterns of growth contributes to an increase in $\mathrm{CO}_{2}$ production, thus directly and negatively impacting on climate change (Ewing et al., 2007; Reid et al., 2007). Current matters such as the financial and energetic crisis are reinvigorating decision-makers and professional interest on the possible remedies to re-addressing the development patterns toward more compact ones (Barnett, 2007). Literature on urban sprawl also demonstrates how scattered and uncontrolled development can produce both environmental and socio-economic interrelated issues (Bank of America, 1996; Burchell et al., 2005; Gillham, 2002; Soule, 2006; Transit Cooperative Research Program, 2002; Williams, 2002; Squires, 2002).

Although increasing compactness is considered the main goal to pursue for an effective sustainable urban management, the way to implement it is paved with many obstacles. A major issue is represented by the fragmented arena of bodies, both public and private, which need to share a common vision and work together to get it. Moreover, it is hard to reconcile the requirement for a sustainable urban growth pattern with genuine respect for institutional stakeholders at different scales; a wide range of blended solutions ranging between formal and informal arrangements seems to be the way of approaching this contested matter (Phares, 2004).

The first goal of this paper is to investigate how to achieve a sustainable growth pattern by making different institutional bodies converge toward a shared vision throughout the whole implementation process. To do that, the paper investigates the case study of the San Diego region, by focusing on the negotiation and implementation process of a regional plan and the related incentive-based programme undertaken by a Californian agency, the San Diego Association of Government (SANDAG). The San Diego region is characterised by a growing population, which is undermining the environment, by creating an increased need for primary agricultural land to be urbanised with detrimental effects on desertification and mobility problems. According to SANDAG (1993), the solution is to re-address the current growth patterns towards more compact ones.

The paper first discusses the results from the negotiation process which led to the construction of a shared spatial framework for the future of the region. After that it evaluates some outcomes from the incentive-based programme intended to implement the plan by applying a qualitative methodology. As highlighted by Bengston et al. (2004), the body of knowledge on the evaluation of empirical implementation cases is still weak. The paper contributes to fill the gap in the literature on the evaluation of actual impacts in growth management strategies, by making primary data on a real implementation case study available and by discussing them in order to draw lessons useful for the international planners and decision makers. 


\section{Putting smart growth principles in practise}

The smart growth movement represents an important contribution from North American planning theory on the issue of curbing urban sprawl (Daniels, 2001; Soule, 2006). Smart growth has been defined in many different ways (Gillham, 2002; Ye et al., 2005; Smart Growth Network, 2001, 2003, 2006); nevertheless, general consensus exists in considering it as part of the broader sustainable planning movement (Wheeler, 2000; Krueger and Gibbs, 2008). As Gillham (2002, p.155) notes, "many of the growth-management planning techniques developed in the past three decades have become instruments in the toolbox of the today's smart growth movement".

The use of smart growth became popular mid-90s thanks to the effort of the Maryland Governor Parris Glendening, whose primary agenda was to turn the state's development pattern into a more sustainable one. In 1997, he proposed a specific piece of legislation (Maryland State Finance and Procurement Code Ann. 5-7B-01), aimed at conserving open spaces and discouraging scattered and leapfrog development which was pioneering in this manner (De Grove, 2005). Furthermore, he led the creation of an initiative that focused on using the entire $\$ 23$ billion state budget as an incentive for smart growth. Smart growth has now extended too many other institutional initiatives by state, regional and local authorities. As Porter (2008) highlights, the common thread which links together the different state-wide initiatives is to put forward incentives and requirements to prevent public and private investment from creating new infrastructure and development outside of the existing built areas. This observation could similarly apply to the regional initiatives. At a local level, smart growth is translated land-development regulations, aimed to disseminate land-use patterns and urban design features supportive of pedestrian-friendly environments and liveable communities (Morris, 2009).

Table 1 Principle of smart growth

1 Creation of a more compact urban form by limiting sprawl at the metropolitan fringe through urban growth boundaries (UGBs) and open space conservation.

2 Revitalisation of existing communities through infill/densification and good community design while optimising existing public facilities.

3 Enhancement of the tax base of inner city and first-ring suburbs through regional tax-base sharing. Also, creation of affordable housing in suburban areas through regional fair-share housing.

4 Redesign of old and new developments on the basis of 'new-urbanism' principles that call for mixed-use centres, job-housing balance, pedestrian-friendly communities, grid-street patterns, alleys, porches, and other design elements that make neighbourhoods vital and diverse.

5 Reorientation of the transportation system to reduce dependency on the automobile through land-use measures as in 4, reallocation of funds of transit, and monetary disincentives, such as higher gasoline tax.

6 Preservation of wildlife habitats, prime agricultural lands, and open space, especially at the urban fringe

Source: Calavita et al. (2005, pp.42-43)

According to Szold and Carbonell (2002, p.3), "to some, smart growth is simply a euphemism for better choices about future development and land use. To others, however, smart growth principles are specifically those that embody viable alternatives to 
prevailing suburban sprawl. When put into practice, these principles promote compact, mixed-use, transit-oriented, and environmentally sound development and land use patterns". The principles of smart growth are summarised by Calavita et al. (2005, pp.42-43) through the six processes shown in Table 1.

According to these principles, it clearly emerges how smart growth needs to be pursued in a complex framework of multi-faceted actions, by embracing a wide array of sectors, both in planning and policy-making fields, and by acting with a multi-level approach. Thus, the strong environmentalist roots of the Smart Growth movement puts (implicitly) forward the vexata quaestio of which level can better address environmentally-related issues, such as protecting the open land on the wider scale, or pursuing an effective public transportation system.

Concerning this issue, it is worth noting that, although North American planning culture has strong regionalist tradition (Fishman, 2000; Mac Kaye, 1962), the actual system never ended up in reality as a consistent re-casting of responsibilities among state-regional-local scales. The US land use planning system is devolved to the jurisdictions of individual states, which determine their own system of relations with their municipalities. On one side, local authorities still hold powers in some crucial areas of concern, such as land use planning; on the other side, many authors such as Weitz (1999), Williams (2000) and Bronin (2008) assert the importance of the role of the state in ensuring effective environmental planning, though lacking in conclusions on how to avoid clashes with the subsidiarity principle.

Similarly, the regional scale is often pointed as more appropriate than the local one in managing growth-related issues and also in this case, it appears as 'antagonistic' to the local governments. Downs $(2005$, p.370) complains that a sort of "disjointed incrementalism" is still "the overwhelmingly dominant method used in American metropolitan areas, mainly because there are very few effective regional bodies with the authority to influence where future growth will occur". A current emerging movement is the so-called 'new regionalism' (Wheeler, 2002; Orfield, 1997), which emphasises the role of the regional level in planning and governance systems. The Metro Portland case is recognised - with very few opponents (O'Toole, 2001) - as the leading experience in terms of managing the growth, thanks to a well-defined regional government structure, which rests on a real and proper elected body (Metro Portland, n.d.).

From one side, Smart Growth is clearly related to the new regionalism, as some of the policies, such as tax base sharing and planning tools, like the Urban Growth Boundaries, are only manageable at a region-wide scale (Haughton and Counsell, 2004). At the same time, Smart Growth pays particular attention to local community aspects, by emphasising the importance of the socio-economically balanced territorial network and of high physical quality in the local built environment (Calthorpe and Fulton, 2001). In so doing, it emphasises also the social roots of the concept of sustainability, by highlighting the role of the local bodies in designing their future (Beatley and Manning, 1997; Magnaghi, 2000, 2007) and the commitment of local governments to achieve consistent and effective land-use patterns, thus implicitly recognising how in the age of 'decentralised leadership' 'all sustainability is local', as "the leaders who shape the built environment ... number in the millions of people" [Farr, (2007), p.10].

Table 2 is an attempt at visualising the degree of appropriateness of local, regional or state-wide initiatives, in terms of pursuing the different aspects which articulate the complex concept of sustainable planning, drawing from the above mentioned literature. 
Table 2 Degree of appropriateness of local-regional-state initiatives in performing goals related to the different aspects of the complex concept of sustainability with respects to the growth management issues

\begin{tabular}{lccc}
\hline & Local level & Regional level & State level \\
\hline $\begin{array}{l}\text { Performing wider-area environmental goals, } \\
\text { which require a specific technically-oriented } \\
\text { commitment }\end{array}$ & $*$ & $* *$ & $* * *$ \\
$\begin{array}{l}\text { Performing long-term environmental goals, } \\
\text { which require long-standing normative } \\
\text { framework over the time }\end{array}$ & $* *$ & $* *$ & $* * *$ \\
$\begin{array}{l}\text { Capturing the needs of the local communities } \\
\text { and engaging the local actors in the design and } \\
\text { implementation process of plans and policies }\end{array}$ & $* * *$ & $* *$ & $*$ \\
\hline
\end{tabular}

Notes: Legend: $*=$ weak; $* *=$ medium; $* * *=$ high

To overcome the competence issue, the 'trans-scalar' approach to the management of growth can help. According to Governa and Salone (2004), joined-up thinking across different scales allows incorporating the concept of subsidiarity in the decision-making and implementation processes of planning, which requires the proactive contribution of multi-level institutions to be effective. A similar approach has been developed by Neumann (2007) through the conceptualisation of the multi-scalar-large-institutional-network (Mslin). In a Mslin the traditional hierarchical approach is replaced by a network one, which rests on the concept of scale much more than on the concept of level (more hierarchical). Neumann investigates SANDAG as a good example of Mslin, thus reinforcing the choice of San Diego as a relevant case study in terms of its innovative inter-institutional approach to the planning process.

To conclude, smart growth is part of the broader sustainable planning movement and advocates for a compact development growth pattern achievable by involving bodies from different institutional levels with different planning and policy tools. The trans-scalar approach helps to appreciate the importance of all bodies involved in the process, thus supporting an evaluation method of the case study based on the investigation of all the scales involved (local/regional), each one analysed by considering its respective most relevant key-factor (urban design at the local scale, regional planning and policy tools at the regional level). The following section discusses the case study of the San Diego region, in order to draw lessons from successes and failures in the implementation of the growth management strategy.

\section{Setting the context for the case study: smart growth in the San Diego region}

The San Diego region is located on the Pacific Coast south of the Los Angeles metropolitan area and north of the Mexican border; it comprises over 2.7 million acres of land (more than 4,200 square miles), almost the size of the state of Connecticut and has a total population of just over three million, which is rapidly increasing (SANDAG, 2004). 
To cope with this growth and move towards a sustainable and balanced future, the region mainly relies upon the efforts of the SANDAGs, which is the metropolitan planning organisation (MPO) for San Diego County. Currently, "SANDAG is governed by a Board of Directors composed of mayors, council members and county supervisors from each of the region's 19 local governments. Supplementing these voting members are advisory representatives from Imperial County, the US Department of Defence, Caltrans, San Diego Unified Port District, Metropolitan Transit System, North County Transit District, San Diego County Water Authority, Southern California Tribal Chairmen's Association, and Mexico. The Board of Directors is assisted by a professional staff of planners, engineers, and research specialists" (http://www.sandag.org).

The history of SANDAG is the story of the evolution of roles of a network of authorities, which has gradually increased its functions and responsibilities over more than 40 years (Porter, 1998; Calavita et al., 2005; Nelson, 2007). In 1966, the County of San Diego and the 13 cities in the region signed a joint power agreement (JPA) to set up a comprehensive planning organisation (CPO). In 1970, the State of California gave the CPO special powers to undertake the highway construction programme; the CPO was then turned into a MPO. In 1975, the MPO produced the first regional transportation plan (RTP). An important milestone in the SANDAG's history was the County Ballot in 1988, which passed the 'Proposition C', thus allowing the creation of a Regional Planning and Growth Management Review Board for the development of a comprehensive regional strategy. A critical scenario analysis was developed, by comparing the huge land consumption that would have occurred if the growth trends had not changed, and the more sustainable growth that a compact pattern could ensure instead (one third of new land wasted).

On the basis of this forecast, in 1993 SANDAG adopted a Regional Growth Management Strategy. After a long stage of forecasting efforts and consensus building (SANDAG, 1993, 1999), another achievement was the adoption of the regional comprehensive plan (RCP) in 2004. The first goal of SANDAG's RCP was to provide a cross-cutting physical frame in which different policies (environmental, transportation, housing, economic policies) can be designed and implemented (SANDAG, 2004). The RCP includes a smart growth concept map, a spatial framework, without any land-use effects aimed at guiding the concentration of the growth to the so-called 'Smart Growth Opportunity Areas' (SANDAG, 2006).

The criteria used to design these areas into a balanced territorial frame rest on the two major key-factors leading the growth process: density and accessibility. The underlying rationale is that each single area plays a role in the network, according to the density of uses (residential uses expressed as dwelling units per acre, i.e., du/c, and productive uses, expressed as employers per acre, i.e., emp/ac) and according to the degree of connection within the regional transportation system (ranking from the highest level of accessibility, which implies frequent connection at the interregional scale, to the lower level of accessibility, which implies a fair local transportation service).

The entire region, regardless of administrative boundaries, is re-designed in shape of a network of nodes, by ranking each node as 'metropolitan centre', 'urban centre', 'town centre', 'community centre', 'rural village' according to its level of accessibility and density, and by labelling as 'smart growth opportunity areas' those areas in which growth should concentrate. The following matrix (SANDAG, 2004) reports the thresholds admitted for each type of area. 
Table 3 Ranking of the smart growth opportunity areas according to their correspondent levels of accessibility/density

\begin{tabular}{lcc}
\hline Smart growth place type & $\begin{array}{c}\text { Minimum residential and } \\
\text { employment targets }\end{array}$ & $\begin{array}{c}\text { Minimum transit service } \\
\text { characteristics }\end{array}$ \\
\hline Metropolitan centre & $75+\mathrm{du} / \mathrm{ac} ; 80+\mathrm{emp} / \mathrm{ac}$ & Regional \\
Urban centre & $40+\mathrm{du} / \mathrm{ac} ; 50+\mathrm{emp} / \mathrm{ac}$ & Corridor \\
Town centre & $20+\mathrm{du} / \mathrm{ac} ; 40+\mathrm{emp} / \mathrm{ac}$ & Corridor/community \\
Community centre & $20+\mathrm{du} / \mathrm{ac}$ & High frequency local \\
Rural village & $10,9+\mathrm{du} / \mathrm{ac}$ & N/A \\
Mixed use transit corridor & $25+\mathrm{du} / \mathrm{ac}$ & High frequency local \\
Special use centre & Ort.res.; $50+\mathrm{emp} / \mathrm{ac}$ & High frequency local \\
\hline
\end{tabular}

Source: SANDAG (2004)

Thus, the smart growth concept map points out about 200 'Smart growth opportunity areas', i.e., 'places that accommodate, or have the potential to accommodate, higher residential and/or employment densities near public transit': meaning that smart growth opportunity areas can either be already supported by an adequate level of accessibility ensured by the regional transportation system and density provisions in the land-use local plans, or, they can be potentially 'equipped' to accommodate future growth. In this latter case, this would imply an effort either from the regional authority side, by enhancing the accessibility level in the designated areas, or from the local governments, which commit themselves to up-zone the current land-use plans consistent with the thresholds set in the matrix.

Figure 1 Smart growth opportunity areas concept map

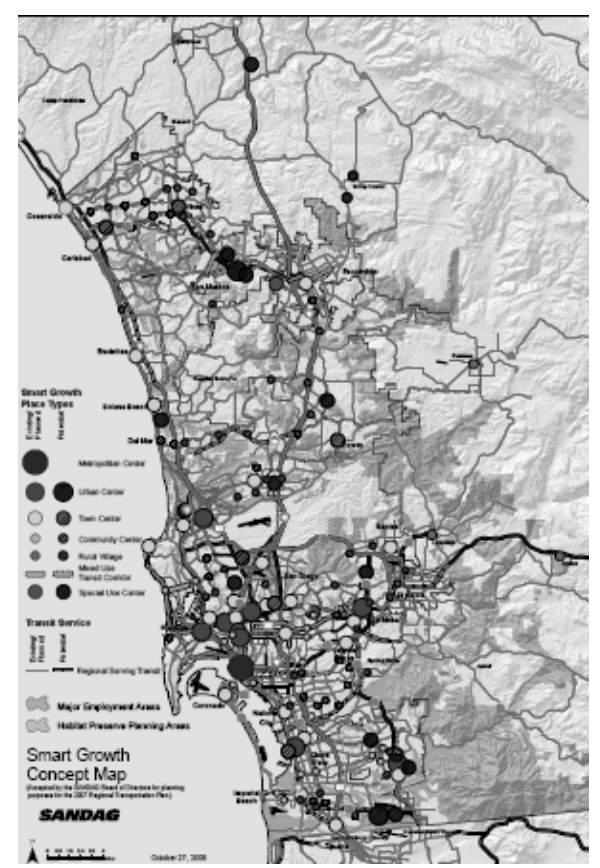

Source: SANDAG (2004) 
The negotiation process which led to the definition of the smart growth opportunity areas deserves a proper discussion as it embeds the challenging matter of how to build a long-term and wide scale physical pattern for the growth of the entire region by making regional and local authorities work together. The designation of the existing and proposed smart growth opportunity areas stems from a two-way negotiation process, where the specific contribution of regional and local bodies was first of all sharing the knowledge appropriate to their level of competence. Urban and transportation planners from SANDAG made considerable efforts in terms of producing in-depth regional analysis and forecasts, in order to create the framework for choosing the best alternative spatial vision, suitable to comply with the criteria of underpinning a wide consistent backbone for the future growth and of maximising the sustainability criteria through the available infrastructural and environmental assets.

Starting from this very detailed analysis, criteria were chosen to lead the selection of the areas according to the previously built spatial pattern. The criteria were then discussed and shared with the local authorities. These authorities, thanks to their in-depth knowledge of the territory, were able to indicate which specific areas better fitted the criteria of selection and discussed them with the SANDAG planners. Following the selection of the areas, local authorities took responsibility for aligning local planning tools to the RCP. At the end of this process, the smart growth opportunity areas map was defined and incorporated as part of the RCP (interview with Caroline Gregor, 7th December 2007).

The smart growth opportunity areas concept map, as a matter of fact, represents a huge achievement in itself, as it is the blueprint for the actual implementation of regional and local strategies and allows the coordination of all efforts toward a shared spatial vision and orienting the allocation of public and private investments in a way which is consistent with the growth management goals. Achieving compactness requires a spatial vision to be followed, thus implying a consequent land-use and a supporting system of measures, such as regulations and incentives. Each of these needs to be performed in coordination across all the bodies involved in the planning and policy-making process, according to the specific government system in force. In the San Diego case, local authorities are responsible for the land-use; they therefore need to be not only aware but also be proactive in implementing densification strategies in their respective cities. In other words, the actual spatial framework for the implementation of an effective regional growth management strategy cannot skip the genuine commitment of local authorities, which are altogether responsible for the successful implementation of the regional plan. Thus, investigating the successful implementation of the regional plan implies a careful analysis of what happens at the local scale, and this is what will be provided through the empirical research presented in the following section.

\section{Implementing smart growth in the San Diego region}

As discussed in the previous section, following a long negotiation process, SANDAG is currently seeking to implement the RCP, although it is lacking in land-use powers. Thus, the RCP goals will be achieved only if local governments are pro-active in its implementation, by turning land-uses, currently inconsistent with the RCP, into consistent ones, and by increasing density and urban quality in some strategic areas. The 
effective implementation of the growth management strategy underpinned in the RCP is nowadays the real challenge. This section investigates how it is possible for the regional authority to facilitate the implementation of the Smart Growth, by analysing successes and failures of the current implementation process. This process is mainly boosted by a set of incentives, under the TransNet Smart Growth Incentive Program (SANDAG, 2005). A key element of SANDAG's strategy is to provide financial support to those localities that contribute to implementing the smart growth opportunity areas requirements. As the programme has run for a few years, it would have not made sense to investigate its long terms impacts on the growth patterns in quantitative terms (Lewis et al., 2009); at the same time, the chosen research method was aimed at capturing the complexity of the programme outcomes, both in terms of physical outputs, and of interaction among the actors involved in its implementation.

\subsection{Methodology}

The research methodology was based on a qualitative approach, aimed at investigating the complexity of the implementation process of the growth management strategy in the San Diego region using primary and secondary data. Literature and official documents on the San Diego regional context, on the history of SANDAG and of the different steps which led to finalise the current RCP version were first gathered and analysed. This allowed the context for assessing the incentive-based programme within its institutional and physical specific framework to be set. The desk analysis was complemented by 30 semi-structured interviews with key stakeholders, from the public sector (SANDAG, City of San Diego, San Diego County, other cities involved in the RCP), from the third sector (environmental associations, groups of interests) and from the academic world. After that, the research focused on the incentives programme aimed at facilitating the RCP actual implementation, i.e., the TransNet Smart Growth Incentive Program. A group of 16 smart growth opportunity areas were first investigated through desk analysis of planning documents (land-use plans, site design regulations, urban design projects...) and field work (photo survey). The selection of these areas was based on the criteria to cover the whole territory included in the RCP.

Then, three SGOAs targeted by the Incentive Programme were selected for further in-depth study. The selection was discussed with the SANDAG officers in order to choose those SGOAs, in which the incentives were already turned into actual developments, in order to assess tangible results. An in-depth desk analysis of the documents related to the incentive programme was first conducted, followed by more specific four semi-structured interviews with city planners involved in the delivery of the incentive programme at local level. Further field work was conducted, in order to assess the areas in different conditions. The areas were investigated by driving, by riding public transport and by walking and talking, when possible, to people in the area. A detailed description for each area was created, supported by a photographic-survey, maps, written notes on the environment and physical conditions. This study was complemented by further analysis on three smart growth opportunity areas not (yet) targeted by the incentive programme. Finally, the research findings were discussed with a panel of three experts from SANDAG and five from the academic environment, with the aim to assess the research results and to improve some details. 


\subsection{Presentation of the cases}

The TransNet Smart Growth Incentive Program was designed for awarding grants to local government, transit operators and other public agencies on a competitive basis, with the purpose of facilitating the Smart Growth strategy implementation. It was initially launched in 2004 as Pilot Smart Growth Incentive Program by granting 14 projects while the whole programme is financed with 206 billion dollars over 25 years. It pursues the following goals: to fund a broad array of transportation-related infrastructure improvements; to integrate transportation and land use; to enhance streets and public places; to support smart growth opportunity areas; to establish a regional competitive grant programme (SANDAG, 2005). Currently, three of the projects awarded in 2008 have been completed: the Bird Rock Area Traffic Management Plan, whose sponsoring jurisdiction is the City of San Diego in La Jolla Community, three projects merged in one concerning the National City Boulevard in National City, and one project from the City of La Mesa - the Grossmont station (interviews with Stephen Vance, 7th December 2007, 10th January 2008 and 30th April 2009).

The 'Bird Rock Area Traffic Management Plan' was sponsored by the City of San Diego; the total cost of the capital investment was $\$ 4,285,999$ which refers to the public realm works (interview with Slawash Pazagardi, 21st January 2008). The community suffered from dangerous exposure to high speed traffic when crossing the boulevard which also produced a decrease in development of commercial and recreational activities along it. As it emerges from the planning documents gathered, through a participatory planning process, supported by a Charrette involving the local residents including a dynamic group named the Bird Rock Task Force (City of San Diego, 2002a), a site-plan was developed with streetscape improvements (centre landscaped median, bike lanes and reconfiguration of bus stops and parking spaces) and traffic calming measures (roundabouts and pedestrian crossings) (City of San Diego, $2007 \mathrm{a}, 2002 \mathrm{~b}, 2002 \mathrm{c})$.

After several years of work, the site plan was put finally forward by the City of San Diego, which took advantage by the opportunity of the incentive programme, and committed itself to the project success by also adding $\$ 1,432,000$ as matching funds from the development impact fee (DIF) (City of San Diego, 2007b and interview with Charlene Gabriel, 21st January 2008). The public realm improvements encouraged some private developers to invest in the area, which now includes new residential buildings and some shops, even contributing towards the building of public realm improvements, such as part of the sidewalks and landscaping. As emerged from the desk analysis of the Incentive Programme documents, density in the area increased from the existing 20 dwelling units per acre to 30 . The main general local objective of the project, i.e., to revitalise La Jolla Boulevard which was suffering from financial stagnation, has been photographic survey, showing new businesses in the area. The successful factors of this case study are the significant private contribution to public works and a very strong community support long before the regional incentives programme had begun (interview with Slavash Pazagardi, 21st January 2008 and interview with Stephen Vance, 30th April 2009). 
Figure 2 La Jolla Boulevard project, 2009 (author's picture)

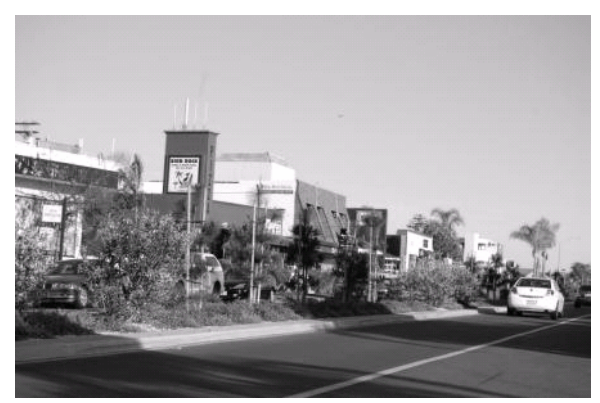

The project 'National City Boulevard Sidewalk and Street lighting Improvement' is located in National City, South of San Diego (interview with Roger Post, 28th January 2008). It is a city deeply influenced by the presence of military areas on the waterfront, which has negatively impacted on the urban environment presenting several areas in blighted conditions. The approved proposal aimed at enhancing the physical quality of a section of National City Boulevard. The RCP classifies the project area as existing 'Town centre' (SANDAG, 2006). Though the area has a high level of accessibility thanks to two trolley (light train) stations and many bus stops for the Metropolitan Transport Service, the specific conditions of the place were quite unpleasant, thus leading the City to adopt in 2005 a Downtown Specific Plan, 'form-based', i.e., emphasising building forms over individual land uses in order to achieve pedestrian friendly communities and mixed-use and transit-oriented development.

Based on the plan, the city expectations were to obtain a variety of low, mid and high-rise buildings of mixed use. The awarded project was originally worth $\$ 3,280,000$ (refers to the capital improvements in the public realm, interview with Stephen Vance, 30th April 2009) with $\$ 1,280,000$ matching funds. The main goal of the project was to enhance the safety and the aesthetic of National City Boulevard whose low quality was an obstacle to pedestrian use and the development of commercial activities. As emerged from the desk analysis of the Incentive Programme documents, the project area includes 13 blocks from the 12th Street to the northern city limit; it had a density of 35 dwelling units per net residential acre while the planned density is 85 dwelling units per net residential acre.

As is evident from the desk analysis of the planning and site-design documents (City of National City, 2005a, 2005b, n.d.), the project consisted of remodelling the streetscape, reducing the number of lanes thus enlarging the pedestrian sidewalks and including traffic calming measures, landscape improvements and new lighting. The project contributed to the catalyst for turning the bad perception associated with the place into a new and positive one, thus attracting private investors. As emerged from the field trip and analysis (interview with Roger Post, 28th January 2008), since the downtown plan has been approved, the number of development proposals has increased. Drawing from the desk and field analysis, it emerges that positive aspects of the project are: it is part of a wider programme of redevelopment of the downtown area; it achieved high physical quality outputs in terms of urban environment and helped in achieving the goal of attracting private investors in the area. 
Figure 3 National City Boulevard project, 2008 (author's picture)

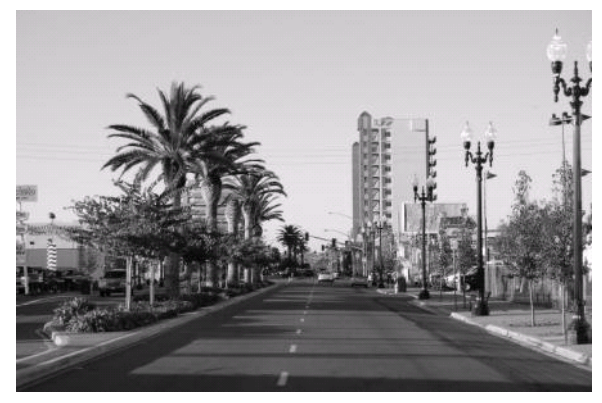

The third examined project is the Grossmont Trolley Station project, located in the City of La Mesa, East of San Diego and it deserves a longer description because of its complexity. The total cost of the public capital investment was $\$ 6,400,000$ (interview with Bill Chopyk, 28th February 2008). The City of La Mesa is served by three freeways and relies on several public transit opportunities. The SANDAG smart growth concept map identified an urban centre in La Mesa, situated where the Grossmont trolley station is. In this area the additional capacity was estimated at 527 additional residential units and 1,081 additional jobs; currently, the vacant acres make up only the $2 \%$ of the total acreage (236).

The Grossmont station is a key centre in La Mesa and in the East County district. Around the transit station is an intensive mixed use area with both residential and commercial uses, although the Grossmont Centre, a regional mall, due to the vicinity to the freeway 8, presents a car-oriented pattern with large parking lots. As emerged from the desk analysis of the Incentive Programme documents, there are approximately 4,000 employers in the area (more than 50 employers per acre), due to the presence of the Grossmont Hospital Medical Complex (which is expanding further) and other commercial and medical offices. The idea of the City of La Mesa was to turn the transit stop and parking lot at the Grossmont transit station into a transit oriented development (TOD).

As the site is connected by two trolley lines and five bus routes no improvements in transit were necessary. The site before the project consisted of a trolley station with a 600 space public parking lot (park and ride) on an area owned by MTS; the trolley line lies at the same level as the parking lot while on the opposite side the Grossmont Centre stands on a steep hill and can be reached by a narrow stair. As emerged from the desk analysis of the Incentive Programme site plan, the new site will rely in the future on an elevator and pedestrian bridge to better connect the two sides of the trolley station as well as a dense mixed-use apartment community of residential and retail space built on the former 600 space parking lot, which includes 1,391 spaces inside the building itself. Affordable housing is also available in the new apartment building. The picture taken before and after the construction of the apartment building shows how the project contributed to create a liveable and walkable environment. The safety conditions of the station were also considerably enhanced by the social control ensured by the presence of more people in the area. 
Figure 4 The Grossmont station before the project completion, 2007 (author's picture)

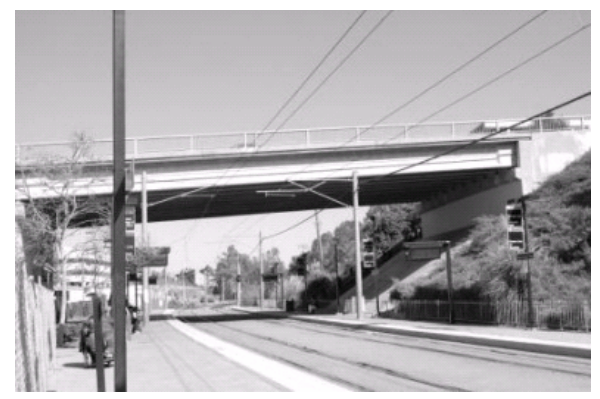

Figure 5 The Grossmont station after the project completion, 2009 (author's pictures)
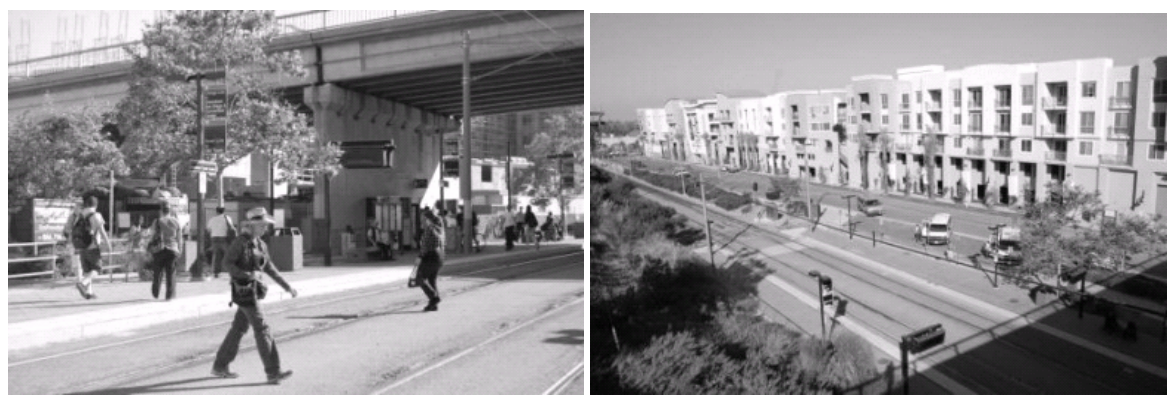

As emerges from the desk analysis, a key-factor in the success of this project, which appears well-integrated both in physical and in social terms, was an existing land-use plan, which allowed designers to organise different functions (such as parking, residential and commercial uses) vertically ending up with a very dense pattern, rich in uses and users (City of La Mesa, 2007). Another interesting aspect of this project concerns the existence of a feasibility study, well prepared and even awarded (Keyser Marston Associates Inc., 2000), which demonstrated the feasibility for the implementation of a TOD in the area; hence, an interest in building the project was present before the Incentive Programme had been launched. To sum up, success factors in this case are: an innovative zoning which allows the integrating of different uses and functions in a public area and a strong vertical integration which achieves a high density just adjacent to the transit station, thus reinforcing the social control on the public space and its liveability.

\subsection{Analysis of the cases}

To make the cases comparable, a set of criteria for evaluating the success of the smart growth principles implementation was constructed, drawing from the literature referred to the regional and to the local scale features which could have an impact in contributing to achieve the smart growth RCP goals. Thus, evaluation criteria matrix took in consideration both, the local area features and, the quality of the connection of the local area to the wider regional network (SANDAG, 2007), in order to approach the SGOA with a trans-scalar perspective. More in depth, the criteria were constructed taking in account the key-features related to the local area, investigating whether or not it was dense enough, mixed-use and pedestrian-friendly oriented, and to the regional 
transportation system. For each criterion the specific normative tool of control was identified and related to the respective key-actor in charge of modifying it, to evidence issues and responsibilities, as summarised Table 4.

Table 4 Evaluation criteria of the successful implementation of the smart growth principles in the areas

\begin{tabular}{lcc}
\hline Criteria & Tools & $\begin{array}{c}\text { Actor } / s \\
\text { involved }\end{array}$ \\
\hline Public transit effectiveness & RTP & SANDAG \\
Density of people and mixed uses & Land-use plans & City \\
Land use around discouraging the use of the automobile & Land-use plans & City \\
Urban design that is supportive of pedestrian and transit & Site plans & City/developers \\
uses & & \\
\hline
\end{tabular}

Table 5 Evaluation of the three selected areas, targeted by the incentive programme

\begin{tabular}{|c|c|c|}
\hline Project and criteria & Evidence & Score \\
\hline \multicolumn{3}{|c|}{ Bird Rock } \\
\hline $\begin{array}{l}\text { Public transit } \\
\text { effectiveness }\end{array}$ & Fair level of accessibility thanks to some frequent buses & $* * *$ \\
\hline $\begin{array}{l}\text { Density of people and } \\
\text { uses }\end{array}$ & $\begin{array}{l}\text { Fairly increased density in residential and commercial uses, } \\
\text { with some effort of vertical integration }\end{array}$ & $* * *$ \\
\hline Land use & Fairly integrated zoning among different uses & $* * *$ \\
\hline Urban design & $\begin{array}{l}\text { Pedestrian-friendly environment, safe and with some } \\
\text { landscape amenities }\end{array}$ & $* * * *$ \\
\hline \multicolumn{3}{|c|}{ National City Boulevard } \\
\hline $\begin{array}{l}\text { Public transit } \\
\text { effectiveness }\end{array}$ & $\begin{array}{l}\text { Very high level of accessibility thanks to the presence of } \\
\text { two trolley stations offering a high frequency service plus } \\
\text { some buses }\end{array}$ & $* * * *$ \\
\hline $\begin{array}{l}\text { Density of people and } \\
\text { uses }\end{array}$ & Very high level of density of uses and vertical integration & $* * *$ \\
\hline Land use & $\begin{array}{l}\text { Integrated zoning, also thanks to the presence of a } \\
\text { redevelopment zone }\end{array}$ & $* * *$ \\
\hline Urban design & $\begin{array}{l}\text { Good quality of the urban environment achieved in the } \\
\text { National City Boulevard project area, safe and with some } \\
\text { landscape amenities }\end{array}$ & $* * *$ \\
\hline \multicolumn{3}{|c|}{ Grossmont station } \\
\hline $\begin{array}{l}\text { Public transit } \\
\text { effectiveness }\end{array}$ & $\begin{array}{l}\text { Very high level of accessibility thanks to the presence of } \\
\text { two trolley lines serving the station and offering a high } \\
\text { frequency service }\end{array}$ & $* * * *$ \\
\hline $\begin{array}{l}\text { Density of people and } \\
\text { uses }\end{array}$ & Very high level of density of uses and vertical integration & $* * * *$ \\
\hline Land use & Best practice case in the integration of uses on a public area & $* * * *$ \\
\hline Urban design & $\begin{array}{l}\text { Good quality of the urban environment achieved in the } \\
\text { Grossmont station project area, safe and with a new elevator } \\
\text { connecting different levels }\end{array}$ & $* * *$ \\
\hline
\end{tabular}


The matrix was tested by applying it to the project targeted by the incentive programme and by attributing to each criterion a qualitative score $(* * * *=$ very good; $* * *=$ good; $* *=$ medium $; *=$ scarce). The evaluation was supported by the evidence gathered through primary (interviews and field trips) and secondary (plans and other documents) data collection. Table 5 shows the results.

The selected areas, targeted by the incentive programme, show a high level of performance according to the criteria, thus demonstrating the ability to maximise the principles embedded in the smart growth approach by properly involving all the bodies responsible for the correct implementation of the programme. The evidence of the considered cases shows a clear commitment from the side of local bodies (either institutional as the cities, the community or both) before the incentive programme started and leads to the conclusion that the regional intervention acted as a catalyst to induce a virtuous process, which would probably otherwise never have happened.

Finally, the situation in other areas, designated as smart growth opportunity areas by the RCP, but not targeted (yet) by the Incentive Programme, was explored. The selection of those further areas was made by locating them in cities not yet considered and situated in very different socio-economic and environmental context, focusing on two areas in the northern cities of the region (Oceanside and Vista), and on one area in the southern part of the city (Chula Vista), desk analysis of planning documents (ACP-Visioning Planning Ltd., 2007; City of Oceanside, 2002; City of Vista, 2007; City of Chula Vista, 2005), field trips and interviews with local planners (interview with Harold Phelps, 24th January 2008; interview with John Conley, 7th February 2008; interview with Scott Nightingale, 23rd January 2008) showed a lack of coordination from both the local and the regional side.

In the two selected study-areas sited in the cities of Oceanside and Vista, the regional authority provided them with massive investment in terms of public transportation with the construction of a new light rail system called 'Sprinter', as emerges from the RCP. According to the RCP targets and goals, the local governments should respond with a consistent land-use policy aimed at enhancing not only the density but also the pedestrian friendliness of the surrounding areas. What emerged from the desk analysis of the planning documents and from the field work, was: in Oceanside, the existence of non-integrated land-use patterns, in Vista Escondido, the poor quality of the urban environment (which was even further challenged by a planned widening of the existing two lane road). On the other side, in the case of Chula Vista, the promised trolley line, which should have served the new development occurring in the Otay Ranch new towns according to the planning documents, was cancelled for budgetary reasons (interview with Harold Phelps, 24th January 2008) thus weakening the level of accessibility of the area, notwithstanding the huge densification which is occurring in the area and the very high quality provided in the development. Table 6 summarises the findings.

To recap, it should be noted that the incentive programme has acted as a catalyst for the implementation of smart growth principles in those areas already 'committed' to achieving the RCP targets on their own. In these cases the incentive programme probably allowed local authorities to implement projects, that might otherwise either never implemented at all or been implemented with lower quality standards. In these successful cases the regional commitment to implement the incentive programme, testified by the existence of the programme itself, found fertile ground in local authorities or communities already committed to the RCP goals. In the areas not targeted by the programme, no evidence exists that an incentive-based approach can be effective in the 
implementation of the regional strategy. However the Chula Vista case shows how gaps in implementation should not be attributed just to the local scale, as the shortage in finance is a typical case of hindered implementation [Hogwood and Gunn, (1984), p.199].

Table 6 Evaluation of the three selected areas, not targeted by the incentive programme

\begin{tabular}{|c|c|c|}
\hline Project and criteria & Evidence & Score \\
\hline \multicolumn{3}{|c|}{ Rancho de Oro } \\
\hline $\begin{array}{l}\text { Public transit } \\
\text { effectiveness }\end{array}$ & $\begin{array}{l}\text { Very high level of accessibility thanks to the presence of a } \\
\text { new sprinter station }\end{array}$ & $* * * *$ \\
\hline $\begin{array}{l}\text { Density of people and } \\
\text { uses }\end{array}$ & Modest level of density with no vertical integration & $*$ \\
\hline Land use & Scarcely integrated zoning & * \\
\hline Urban design & $\begin{array}{l}\text { Low level of pedestrian accessibility, with wide road to } \\
\text { cross and few pedestrian amenities }\end{array}$ & * \\
\hline \multicolumn{3}{|c|}{ Vista Escondido } \\
\hline $\begin{array}{l}\text { Public transit } \\
\text { effectiveness }\end{array}$ & $\begin{array}{l}\text { Very high level of accessibility thanks to the presence of a } \\
\text { new sprinter station }\end{array}$ & $* * * *$ \\
\hline $\begin{array}{l}\text { Density of people and } \\
\text { uses }\end{array}$ & Mid level of density with no vertical integration & $* *$ \\
\hline Land use & Scarcely integrated zoning & * \\
\hline Urban design & $\begin{array}{l}\text { Low level of pedestrian accessibility with future plans for } \\
\text { widening the existing two-lines road }\end{array}$ & * \\
\hline \multicolumn{3}{|c|}{ Otay Ranch } \\
\hline $\begin{array}{l}\text { Public transit } \\
\text { effectiveness }\end{array}$ & $\begin{array}{l}\text { Modest level of accessibility, with few buses operating on } \\
\text { shared roads }\end{array}$ & * \\
\hline $\begin{array}{l}\text { Density of people and } \\
\text { uses }\end{array}$ & Fair level of density of uses and vertical integration & $* * *$ \\
\hline Land use & Fairly integrated zoning & $* * * *$ \\
\hline Urban design & $\begin{array}{l}\text { Excellent quality of urban design and site planning, with a } \\
\text { highly pedestrian friendly oriented environment, rich in } \\
\text { landscape amenities }\end{array}$ & $* * * *$ \\
\hline
\end{tabular}

\section{Conclusions}

This paper aimed at investigating how an effective growth management strategy can be pursued and whether or not an exclusively incentive-based method can support the goals of smart growth. From the discussion of the case-study two main findings can be drawn:

- the regional incentives programme was effective in local contexts already 'equipped' to positively interact with the proposed tool, in which a lack of finance (and not a lack of planning tools or community consensus) prevented them for turning the plans into reality 
- no evidence has been gathered that those local areas which were originally reluctant to implement the regional plan directions changed their mind as a consequence of the incentives programme.

To explore the first finding in depth, an additional question would be if the incentive programme suffered in terms of deadweight spending, i.e., would the project have been implemented anyway, in absence of the incentives? The fact that the projects were in a stand-by condition for some time, supports the conclusion that in all probability the incentives programme is acting as a real and proper catalyst and that in any case they assist in improving the final built project. The second finding requires further explanation, as it leads to the conclusion that the incentives programme has been ineffective under certain specific circumstances, but the question of who should fill this gap, and how, is still open.

The evaluation of the SANDAG's current incentive programme demonstrates the importance and the limitations of an incentive-based approach in altering current growth patterns towards more sustainable ones.

The findings support the conclusion that an incentive-based approach can be useful in those cases where the incentives act as catalyst of a process already in the air, while on the other side, no evidence exists that it can work effectively with local governments reluctant to cooperate on the achievement of the wider scale goals. The implementation assessment shows that gaps exist which cannot be tackled solely through a 'carrot' approach. Therefore, the paper suggests that an incentive-based approach works better in conjunction with a regulatory framework in order to fill some specific gaps which occur during the implementation process of the plan and to try to improve knowledge of the circumstances in which an incentive-based approach is more likely to fail.

The limitations of this research are due to time constraints which prevented a long-lasting post-completion evaluation of quantitative-based evidences on the wider scale. These limitations would suggest that these types of programmes should be evaluated over the time, to be able to capture both the evidence along the process at local and regional scale, and final impacts at the end of the programme (ongoing evaluation). Drawing inspiration from this research future studies could monitor, discuss and evaluate other programmes by expanding the body of knowledge with further empirical research. The findings of this and further researches would help to clarify which issues often plague the real implementation of strategies aimed at managing growth.

In State of California (2008) passed Senate Bill 375, "Transportation planning: travel demand models: sustainable communities strategy: environmental review". Summarised by the slogan "Reducing Harmful Greenhouses Gases Through Better Land-Use Planning", the Bill "SB 375 provides emissions-reducing goals for which regions can plan, integrates disjointed planning activities, and provides incentives for local governments and developers to follow new conscientiously-planned growth patterns.... SB 375 will be responsible for reshaping the face of California's communities into more sustainable, walkable communities, with alternative transportation options and increased quality of life" (State of California, 2008).

Despite the fact that the Bill "requires metropolitan planning organizations (MPOs) to include sustainable communities strategies (SCS) as defined in their regional transportation plans (RTPs) for the purpose of reducing greenhouse gas emissions, aligns planning for transportation and housing and creates specified incentives for the implementation of the strategies", some scepticism has already arisen. As Fulton (2008) 
argues, "SB $375 \ldots$ is both more and less powerful than it's advertised to be", as its applicability will be seriously challenged both by the incentive-based approach followed by the Californian regional authorities and because the "local governments don't have to comply with the (regional) plans". This controversial context demonstrates the need for more evidence-based studies focused on the effectiveness of an incentives-based approach demonstrating both the advantages and the limitations of it.

The issues covered in the paper are not restricted to either the Californian or the US framework. The literature underlines how sprawl currently plagues the EU area as well (Couch et al., 2007; Richardson and Bae, 2004). Evidence exists that it has even increased further in those areas targeted by European Union spending (European Commission, 2006). This observation adds evidence to a very controversial issue. While at planning policy level the European Union through the European Spatial Plan advocates for a polycentric development pattern (Davoudi, 1999; Faludi and Waterhout, 2002; DeMatteis, 2005), in practise it seems incapable of managing the side-effects of the incentives which finally can result in drivers for uncontrolled growth and urban sprawl.

As a matter of fact, the EU-Polycentrism principles (Nordregio, 2005) recall some key-concepts embedded in the US-smart growth movement as they both:

- aim to pursue environmental goals, by reducing the land waste and to enhance the proactive role of rural areas in balancing urban growth (Bengs and Schmidt-Thomé, 2005)

- underline the importance of the transportation and land-use nexus as the backbone of a balanced and efficient growth pattern (Hajer, 2000)

- emphasise the role of both small and big centres in contributing to the best performance of the entire net (Governa and Salone, 2005).

The similarity of some issues suggests that insights drawn from the smart growth experience can be applied to the European context as well; not only helping planners and decision-makers in formulating and delivering appropriate strategies for growth management but also in redirecting European incentive policies which might unwillingly act as catalysts for urban sprawl.

\section{Acknowledgements}

This paper draws from a research granted by a Fulbright Senior Research Scholarship. The author wishes to warmly thank the referees for their constructive criticisms to the original version of the paper and Professors Nico Calavita and Stanley McGreal for their advice. All the possible mistakes are of course the author's only responsibility.

\section{References}

Bank of America (1996) Beyond Sprawl: New Patterns of Growth to Fit the New California, Bank America Corporation, San Francisco, CA.

Barnett, J. (Ed.) (2007) Smart Growth in a Changing World, American Planning Association, Chicago.

Beatley, T. and Manning, K. (1997) The Ecology of Place: Planning for Environment, Economy and Community, Island Press, Washington, DC. 
Bengs, C. and Schmidt-Thomé, K. (2005) ESPON 1.1.2. Urban Rural relations in Europe, Espon Coordination Unit, Luxembourg.

Bengston, D., Fletcher, J.O. and Nelson, K. (2004) 'Public policies for managing urban growth and protecting open space: policy instruments and lessons learned in the United States', Landscape and Urban Planning, Vol. 69, Nos. 2-3, pp.271-286.

Bronin, S. (2008) 'The quiet revolution revived: sustainable design, land use regulation, and the states', Minnesota Law Review, Vol. 93, No. 1, pp.231-273.

Burchell, R.W., Downs, A., McCann, B. and Mukherji, S. (2005) Sprawl Costs: Economic Impacts of Unchecked Development, Island Press, Washington, DC.

Calavita, N., Caves, R. and Ferrier, K. (2005) 'The challenges of smart growth: the San Diego case', in Wagner, F., Joder, T., Mumphrey, A., Akundi, K. and Artibise, A. (Eds): Revitalising the City: Strategies to Contain Sprawl and Revive the Core, pp.41-70, M.E. Sharpe Inc., New York.

Calthorpe, P. (1993) The Next American Metropolis: Ecology, Community, and the American Dream, Princeton Architectural Press, New York.

Calthorpe, P. and Fulton, W. (2001) The Regional City: Planning for the End of Sprawl, Island Press, Washington, DC.

Cervero, R. and Bernick, M. (1997) Transit Villages in the 21st Century, McGraw-Hill, New York.

Condon, P. (2008) 'Planning for climate change', Land Lines, January, Vol. 20, No, 1, pp.2-7, Lincoln Institute of Land Policy.

Couch, C., Leontidou, L. and Petshel-Held, G. (2007) Urban Sprawl in Europe: Landscape, Land-Use Change and Policy, Blackwell Publishing, New York.

Daniels, T. (2001) 'Smart growth: a new American approach to regional planning', Planning Practice and Research, Vol. 16, No. 3, pp.271-279.

Davoudi, S. (1999) 'Making sense of the European spatial development perspectives', Town and Country Planning, Vol. 68, No. 12, pp.367-369.

De Grove, J.T. (2005) Planning Policy and Politics: Smart Growth and the States, Lincoln Institute of Land Policy, Cambridge, MA.

Dematteis, G. (2005) 'Verso un policentrismo europeo: metropoli, città reticolari, reti di città', Urbanistica Dossier, No. 75, pp.19-24.

Downs, A. (2005) 'Smart growth: why we discuss it more than we do it', Journal of American Planning Association, Vol. 71, No. 4, pp.367-380.

European Commission (1999) ESPD, European Spatial Development Perspective, Towards Balanced and Sustainable Development of the Territory of the European Union, European Commission, Luxembourg.

European Commission (2006) Urban Sprawl in Europe: The Ignored Challenge, EEA Report No. 10, European Commission, Luxembourg.

Ewing, R., Bartholomew, K., Winkelman, S., Walters, J. and Chen, D. (2007) Growing Cooler: The Evidence on Urban Development and Climate Change, Urban Land Institute, Smart Growth America, Centre for Air Policy, and Centre for Smart Growth Education and Research, Washington, DC.

Faludi, A. and Waterhout, B. (2002) The Making of the European Spatial Development Perspective, Routledge, London.

Farr, D. (2007) Sustainable Urbanism: Urban Design with Nature, John Wiley \& Son, New York.

Fishman, R. (2000) 'The death and life of American regional planning', in Katz, B. (Ed.): Reflections on Regionalism, pp.107-126, Brookings Institution Press, Washington, DC.

Fulton (2008) 'SB 375 is now law - but what will it do?', California Planning \&Development Report, 1 October, available at http://www.cp-dr.com (accessed on 10 September 2009).

Gillham, O. (2002) The Limitless City: A Primer on the Urban Sprawl Debate, Island Press, Washington, DC. 
Governa, F. and Salone, C. (2004) 'Territories in action, territories for action: the territorial dimension of Italian development policies', International Journal of Urban and Regional Research, Vol. 28, No. 4, pp.796-818.

Governa, F. and Salone, C. (2005) 'Italy and European spatial policies: polycentrism, urban networks and local innovation practices', European Planning Studies, Vol. 13, No. 2, pp.265-283.

Hajer, M. (2000) 'Transnational networks as transnational policy discourse: some observations on the politics of spatial development in Europe', in Faludi, A. and Salet, W. (Eds.): The Revival of Strategic Spatial Planning, Royal Netherlands Academy of Arts and Sciences, Amsterdam.

Haughton, G. and Counsell, D. (2004) Regions, Spatial Strategies and Sustainable Development, Routledge, London.

Hogwood, B. and Gunn, L.A. (1984) Policy Analysis for the Real World, Oxford University Press, Oxford.

Krueger, R. and Gibbs, D. (2008) 'Third wave sustainability? Smart growth and regional development in the USA', Regional Studies, Vol. 42, No. 9, pp.1263-1274.

Lewis, R., Knaap, G-J. and Sohn, J. (2009) 'Managing growth with priority funding areas, a good idea whose time has yet to come', Journal of American Planning Association, Vol. 75, No. 4, pp.457-478.

Mac Kaye, B. (1962) The New Exploration, University of Illinois Press, Urbana.

Magnaghi, A. (2000) Il progetto locale, Bollati Boringhieri, Torino.

Magnaghi, A. (Ed.) (2007) Scenari strategici. Visioni identitarie per il progetto di territorio, Alinea, Firenze.

Morris, M. (2009) Smart Codes: Model Land-Development Regulations, American Planning Association, Report Number 556, Chicago and Washington, DC.

Neumann, M. (2007) 'Multi-scalar large institutional networks in regional planning', Planning Theory and Practice, Vol. 8, No. 3, pp.319-344.

Nordregio (2005) ESPON 1.1.1: Potentials for Polycentric Development in Europe, Espon Coordination Unit, Luxembourg.

O’Toole, R. (2001) The Vanishing Automobile and Other Urban Myths: How Smart Growth Will Harm American Cities, The Thoreau Institute, Bandon, Oregon.

Orfield, M. (1997) Metropolitics, a Regional Agenda for Community and Stability, Brookings Institution Press, Washington, DC.

Phares, D. (Ed.) (2004) Metropolitan Governance without Metropolitan Government?, Ashgate, Aldershot.

Porter, D.R. (1998) 'The states: growing smarter?', ULI on the future-Smart Growth: Economy, Community, Environment, pp.28-35, Urban Land Institute, Washington, DC.

Reid, E., Bartholomew, K., Winkelman, S., Walters, J. and Chen, D. (2007) Growing Cooler: The Evidence on Urban Development and Climate Change, Urban Land Institute, Washington, DC.

Richardson, H.W. and Bae, C.C. (Eds.) (2004) Urban Sprawl in Western Europe and the United States, Ashgate, Aldershot.

Smart Growth Network (2001) Affordable Housing and Smart Growth. Making the Connection, Washington, DC, available at http://www.smartgrowth.org (accessed on 10 September 2009).

Smart Growth Network (2003) Getting to Smart Growth II: 100 More Policies for Implementation, Washington, DC, available at http://www.smartgrowth.org (accessed on 10 September 2009).

Smart Growth Network (2006) This is Smart Growth, Washington, DC, available at

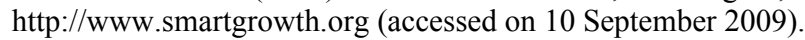

Soule, D.C. (Ed.) (2006) Urban Sprawl: A Comprehensive Reference Guide, Greenwood Press, Westport, CT. 
Squires, D.G. (Ed.) (2002) Urban Sprawl: Causes, Consequences \& Policy Responses, The Urban Institute Press, Washington, DC.

Szold, T.S. and Carbonell, A. (Eds.) (2002) Smart Growth: Form and Consequences, Lincoln Institute of Land Policy, Cambridge, MA.

Transit Cooperative Research Program (2002) Costs of Sprawl-2000, TCRP Report 74, National Academy Press, Washington, DC.

Williams, D.C. (2002) Urban Sprawl: A Reference Handbook, ABC-CLIO, Santa Barbara, CA.

Ye, L., Mandpe, S. and Meyer, P.B. (2005) 'What is 'smart growth?'-really?', Journal of Planning Literature, Vol. 19, No. 3, pp.301-315.

Wheeler, S.M. (2000) 'Planning for metropolitan sustainability', Journal of Planning Education and Research, Vol. 20, No. 2, pp.133-145.

Wheeler, S.M. (2002) 'The new regionalism: key characteristics of an emerging movement', Journal of the American Planning Association, Vol. 68, No. 3, pp.267-278.

Weitz, J. (1999) 'From quiet revolution to smart growth: state growth management programs, 1960 to 1999', Journal of Planning Literature, Vol. 14, No. 2, pp.266-337.

\section{Planning documents and regulations}

Maryland State Finance and Procurement Code Ann. 5-7B-01 (1997)

Metro Portland (n.d.) The Nature of 2040: The Region's 50-Year Plan for Managing Growth, Unpublished.

SANDAG (1993) Regional Growth Management Strategy, San Diego, CA, available at http://www.sandag.org (accessed on 10 September 2009).

SANDAG (1999) Info, 2020 Cities/County Forecast for the San Diego Region, No. 5, September-October, San Diego, CA, available at http://www.sandag.org (accessed on 10 September 2009).

SANDAG (2004) Regional Comprehensive Plan for the San Diego Region, Final Draft, July, San Diego, CA, available at http://www.sandag.org (accessed on 10 September 2009).

SANDAG (2005) Pilot Smart Growth Incentive Program Guidelines, available at http://www.sandag.org (accessed on 10 September 2009).

SANDAG (2006) Draft Smart Growth Concept Map, available at http://www.sandag.org (accessed on 10 September 2009).

SANDAG (2007) San Diego Regional Transportation Plan, available at http://www.sandag.org (accessed on 10 September 2009).

State of California (2008) California Senate Bill 375 (Steinberg) - As Amended, 18 August.

\section{Bird Rock case}

City of San Diego (2007a) General Plan.

City of San Diego (2007b) Attorney's Office Briefing: Facilities Financing Overview, 11 May.

City of San Diego (2002a) Bird Rock Neighborhood Traffic Management, Parking and Traffic Calming Charrette, Final Report, June, Dan Burden Walkable Communities, Inc.

City of San Diego (2002b) Michael Wallkork, La Jolla Boulevard Short Traffic Report, 21 June.

City of San Diego (2002c) Planning Department Facilities Financing, La Jolla: Public Facilities Financing Plan Fiscal Year 2002, June. 


\section{National City Boulevard case}

City of National City (2005a) General Plan, available at http://www.ci.national-city.ca.us (accessed on 10 September 2009).

City of National City (2005b) National City Downtown Specific Plan, available at http://www.ci.national-city.ca.us (accessed on 10 September 2009).

City of National City (n.d.) Plans for the Improvement of National City Boulevard 2nd Street to 12th Street, Project Design Consultants, Unpublished.

\section{Grossmont station case}

City of La Mesa (2007) Zoning Ordinance, available at http://www.ci.la-mesa.ca.us (accessed on 10 September 2009).

Keyser Marston Associates Inc. (2000) Grossmont Trolley Station Transit-Oriented Development Feasibility Planning Study - Assessment of Market Support for Potential Land Uses, 24 April, Unpublished.

\section{Rancho de Oro case}

ACP-Visioning Planning Ltd. (2007) A Vision for the Oceanside Boulevard Corridor, Final Report as Accepted by the Oceanside City Council, 13 November, available at http://www.ci.oceanside.ca.us/obv (accessed on 10 September 2009).

City of Oceanside (2002) General Plan of Oceanside, available at http://www.ci.oceanside.ca.us (accessed on 10 September 2009).

\section{Vista Escondido case}

City of Vista (2007) Preliminary Plan for the Vista Redevelopment Project Area, Amendment No. 4, 26 November, available at http://www.cityofvista.com (accessed on 10 September 2009).

\section{Otay Ranch case}

City of Chula Vista (2005) General Plan of Chula Vista, available at http://www.ci.chulavista.ca.us (accessed on 10 September 2009).

\section{Interviews}

Bill Chopyk, Planning and Development Service Director, 28 February 2008.

Caroline Gregor, Senior Regional Planner a SANDAG, project manager for the SGOAs map: 7th December 2007.

Charlene Gabriel, Facilities Financial Manager at the City of San Diego, responsible for the DIF application, 21st January 2008.

Harold Phelps, Community Planner at the City of Chula Vista, 24th January 2008.

John Conley, Community Development Director at the City of Vista, 7th February 2008.

Roger Post, Planning Director at the City of National City, 28th January 2008.

Scott Nightingale, Planner at the City of Oceanside, 23rd January 2008.

Slavash Pazargadi, Senior Traffic Engineer at the City of San Diego, responsible for the Bird Rock SGIP funded project, 21st January 2008.

Stephan Vance, Senior Regional Planner a SANDAG, project manager for the Smart Growth Incentives Program: 7th December 2007, 10th January 2008, 30th April 2009. 